\title{
Education and Training in Enhancing Performance of Indonesia Port Corporation Employees
}

\author{
Arief Aliman \\ Sekolah Tinggi Ilmu Administrasi \& Manajemen Kepelabuhanan \\ Barunawati Surabaya, Indonesia
}

\begin{abstract}
The aim of this study is to examine the relationship of education and training to performance either individually or jointly. Variables of education and training serve as independent variables while the dependent variable is performance. The study was conducted on randomly selected 100 employees of Indonesia Port Corporation II in Surabaya Indonesia. The study quantitatively reveals that there is a positive significant relationship among variables under the following distribution of coefficient of correlation: education to performance $=0.507$, training $=0.474$ and when tested together it produces coefficient of correlation $=0.884$ and coefficient of determination $=0.712$ indicating the existence of other $28.8 \%$ variables not including in the model affecting performance within the Indonesian state-owned corporation.
\end{abstract}

Keywords: education, training, performance, Indonesia Port Corporation.

\section{INTRODUCTION}

It is widely acknowledged that while the concept of training is endorsed by many managers in harbor industry, very few managers put these ideas into practice. Thus training and educational strategies play lesser roles within the harbor industry, than those of other service industries. Despite this, training can be an important tool in coping with environmental changes, economic success, skill development, improved profit margins and lower levels of labour turnover.

There are several reasons for the lack of employee training. First, many proprietors and managers have had no formal training themselves and are unaware of the benefits of training. Second, many employers are concerned with immediate operational problems, and as such do not have time to plan ahead. Finally, many believe it is the responsibility of others, such as colleges, to provide them with trained staff. While the costs of training are up front and obvious, the benefits are frequently unmeasurable. Therefore, in the majority of organisations, training remains theory as opposed to reality. Port managers appear to be unaware that training can no longer be viewed as a one-time activity designed to equip people with skills for life. Instead it must be recognised that the function of training is an on-going process

Based on the background and the results of the identification of the problem, the formulation of the problem is:

1. Does education positively affect performance?

2. Does training positively affect performance?

3. Do education, and training status simultaneously affect performance?

\section{LITERATURE REVIEW}

One way to develop and improve the quality of employees is to provide them with beneficial training and development programs. This is because the capabilities, knowledge, and skills of the talented employees were proved to be the key determinants competitive advantage in global marketplaces (Becker et.al, 2014). To effectively develop such knowledge, skills and capabilities of employees in order to perform well on the job, training programs are very important in supporting all organizational members. Hafeez and Akbar (2015) reported that that the more the employees receive training, the more efficient their level of performance would be. 
The key principles of training emphasize on providing meaningful inputs for employees based on relevant theories, and to take into consideration the features of effectiveness and efficiency, differences among employees, and continuous development (Diab \& Ajlouni, 2015). Employee training refers to programs that aim to provide employees with required information, new skills to enhance the opportunities of professional development (Elnaga \& Imran, 2013). Training is associated with the skills that an employee should gain to help him by working with others in an attempt to achieve organizational goals and objectives (Truitt, 2011). Sabir, Akhtar, Bukhari, Nasir, and Ahmed (2014) thought about training as the acquisition of knowledge, skills, and abilities by professional development. Similarly, Singh and Mohanty (2012) revealed that the investments in employee training result in beneficial organizational outcomes.

According to Edy Sutrisno (2011) education is the totality of human interaction for full human development, and education is a process that is constantly evolving. Learners are input, after experiencing the educational process by utilizing the educational goals: resources of the existing curriculum that result in output of certain capabilities, so it can be said that it is the change in behavior including knowledge, attitudes, actions, appearance and so on.

According to Anwar Prabu Mangkunegara (2001) the term "performance" refers to achievements of someone actually achieved. Job performance is the result of the quality and quantity achieved an employee in fulfilling their duties in accordance with the responsibilities assigned to him, while according Hasibuan (2011) notion of performance is the result of someone achieves in fulfilling their duties that assigned to them based on skills, experience, and determination as well as time.

Based on above description, hypothesis formulated is: education significantly affects performance (H1), training significantly affects performance $(\mathrm{H} 2)$, education and training simultaneously affect performance $(\mathrm{H} 3)$.

\section{Data Collection}

Descriptive statistics and quantitative analysis are used for finding initial solution to the problem encountered. The sample of this study were 100 permanent employees of Indonesia Port Corporation II located in Surabaya, East- Java Indonesia.

Techniques of data collection in this study is in the form of questionnaire. The normality assumption is prerequisites to proceed to further test. Analysis is conducted with multiple linear regression and hypothesis testing is performed at a significance level of 0.05 .

\section{RESUlt AND DisCUSSION}

Employees of the organisations were asked to participate in the survey by responding their opinions for three different measures in education, training and performance. The normality is performed with Lilliefors test. Data are normally distributed as the value of each variable is not exceeding the critical value for Lilliefors test. The Lilliefors normality test values for education, training and performance are $0.052,0.061$ and 0.063 respectively below the critical value of 0.093 for $n=100$.

\subsection{The Effect of Education to Performance}

Hypothesis testing confirms that education positively affects performance with correlation coefficient value of 0.507 and the coefficient of determination $=0.257$. This means that $25.7 \%$ of employees' performance is determined by education while the other $74.3 \%$ is contributed by other variables.

This finding is in line with Rosenthal et.al, (2003) who we evaluated the effect of education alone followed by education plus performance feedback .They also evaluated the relationship between the administrative support and Health Workers (HW) adherence. The baseline rate of HW before contact with patients was $17 \%$. With education, HW before contact with the patients increased to $44 \%$. Using education and performance feedback HW further increased to $58 \%$.

In context of Indonesia, this finding support Ningrum (2013) who prove that after attending education and training, employees are able to complete work in accordance with company standards, an increase in the precision, accuracy and neatness of the work in accordance with quality standards of the company, employees become more responsible in the field of their work, and are able to adjust the quality of the work with the expectation of the company, employees are punctual in performing tasks or jobs according to targets predetermined by companies. 
Thus, this finding strengthens the previous research on the effect of education to job performance.

\subsection{The Effect of Training to Performance}

Hypothesis testing confirms that training affects performance with the correlation coefficient value of 0.474 and coefficient of determination $=0.225$. This means that $22.5 \%$ of performance is determined by training while the other $77.5 \%$ is contributed by other variables.

This is consistent with Arco (2008) who reviewed observational studies that examined feedback for changing staff performance in behavioral treatment programs for clients with cognitive, developmental, or psychiatric disorders. The research findings were integrated into the main stages of staff training and management: pretraining, training, and posttraining. Specific recommendations for using feedback are made including defining process and outcome form and content before training, providing on-the-job supervisory feedback while staff practice self-generated outcome feedback until competency is demonstrated, and after training, maintaining self-generated feedback with emphasis on evaluating staff and client interactions with social validity measures.

Previous study in Indonesia also has shown that training has a positive relationship to performance (Simamora, 2006) who opined that training is a systematic process of changing the behavior of the employees in a direction to improve organizational goals. Training creates an environment where employees can acquire or learn the attitudes, abilities, skills, knowledge, and behaviors that are specifically related to the job. Training is usually focused on providing employees with special skills or help them correct the weaknesses in their performance.

Thus, this finding strengthens the previous research on the effect of training to job performance.

\subsection{Interaction of Education and Training to Performance}

When tested together, hypothesis testing results show that there is a significant relationship among education and training to performance. The regression equation generated is $249.54+0.916 \mathrm{X} 1+$ $0.058 \mathrm{X} 2$ with correlation of coefficient values $=0.884$ and the coefficient of determination $=0.712$. This means that $71.2 \%$ of performance is caused by variables of education and training while $28.8 \%$ is contributed by other variables not included in the model. The results show Employee's Education and Training together significantly influence employees' performance at Indonesia Port Corporation II Surabaya, Indonesia. It means that the success of an organization is influenced by the performance of employees. Performance is the result of work achieved by an employee in performing tasks according to responsibilities given to him. In this research, factors affecting performance is the level of education and training.

\section{Conclusion}

The findings reveal that there is a positive and significant direct effect of education and training to performance. Based on the initial design of the constellation between variables, the results showed that the contribution of education to performance is $25.7 \%$ and training is $22.5 \%$, indicating the highest individual contribution to the employees, performance among employees of Indonesia Port Corporation II is education. When combined together, a contribution of the two variables of education and training reaches $71.2 \%$ indicating the contribution of other variables not included in the model to predict performance is $28.8 \%$ indicating this model is of good-fit. However, other researchers wishing to conduct similar studies necessary to research the different organizations either use the same model and concept or by adding motivation variable as an intervening variable or some other variables that are likely able to describe phenomena that arise in trying to explain the aspects to improve employees' performance.

\section{REFERENCES}

Arco, L. (2008). Feedback for improving staff training and performance in behavioral treatment programs. Behavioral Interventions, 23(1), 39-64.A

Becker, M., Neumann, M., Tetzner, J., Böse, S., Knoppick, H., Maaz, K., ... \& Lehmann, R. (2014). Is early ability grouping good for high-achieving students' psychosocial development? Effects of the transition into academically selective schools. Journal of Educational Psychology, 106(2), 555 . 


\section{Arief Aliman}

Diab, S. M., \& Ajlouni, M. T. (2015). The influence of training on employee's performance, organizational commitment, and quality of medical services at Jordanian private hospitals. International Journal of Business and Management, 10(2), 117.

Elnaga, A., \& Imran, A. (2013). The effect of training on employee performance. European Journal of Business and Management, 5(4), 137-147.

Hafeez, U., \& Akbar, W. (2015). Impact of Training on Employees Performance (Evidence from Pharmaceutical Companies in Karachi, Pakistan). Business Management and Strategy, 6(1), 4964.

Hasibuhan, Malayu. 2011. Manajemen Sumber Daya Manusia Edisi Revisi. Jakarta: PT Bumi Aksara

Mangkunegara, A, Anwar Prabu. 2009. Manajemen Sumber Daya Manusia. Bandung: PT Remaja Rosdakarya

Ningrum, W. (2013). PENGARUH PENDIDIKAN DAN PELATIHAN TERHADAP KINERJA KARYAWAN (Studi Pada Karyawan Joint Operating Body Pertamina-PertoChina East Java). Jurnal Administrasi Bisnis, 6(2).

Rosenthal, V. D., McCormick, R. D., Guzman, S., Villamayor, C., \& Orellano, P. W. (2003). Effect of education and performance feedback on handwashing: the benefit of administrative support in Argentinean hospitals. American journal of infection control, 31(2), 85-92.

Sabir, R. I., Akhtar, N., Bukhari, F. A. S., Nasir, J., \& Ahmed, W. (2014). Impact of Training on Productivity of Employees: A Case Study of Electricity Supply Company in Pakistan. International Review of Management and Business Research,3(2), 595.

Singh, R., \& Mohanty, M. (2012). Impact of training practices on employee productivity: A comparative study. Interscience Management Review (IMR), 2(2), 74.

Simamora, Henri. 2006. Manajemen Sumber Daya Manusia Edisi 3. Yogyakarta: STIE YKPN

Sutrisno, Edy. 2011. Manajemen Sumber Daya Manusia. Jakarta: Kencana

Truitt, D. L. (2011). The effect of training and development on employee attitude as it relates to training and work proficiency. SAGE Open, 2158244011433338. 